\title{
Adenosine Deaminase and Guanosine Deaminase Activities in Sera of Patients with Viral Hepatitis
}

\author{
Ahmet Kalkan, Vedat Bulut*/+, Ozcan Erel, Senel Avci**, \\ Namik Kemal Bingol***
}

\begin{abstract}
Clinical Microbiology and Infectious Diseases Department *Microbiology and Clinical Microbiology Department, Immunology Division, Firat Medical Centre, Medical School, Firat University, Elazig, Turkey ${ }^{* *}$ Clinical Biochemistry Department, Medical School, Harran University, Sanliurfa, Turkey ***Biochemistry Department, Gulhane Military Medical Academy, Ankara,Turkey
\end{abstract}

In order to investigate purin and primidin metabolism pathways in hepatitis, adenosine deaminase $(A D A)$ and guanosine deaminase (GDA) activities in sera of patients with different types and manifestations of viral hepatitis disease ( $A, B, C, D, E$, chronic, acute) were investigated and compared with the control group of healthy individuals. Hepatitis cases were classified with respect to their serological findings and clinics.

When compared all the hepatitis cases with the controls, levels of aspartate aminotransferase, alanine aminotransferase, and alkaline phosphatase enzymes, as well as ADA and GDA, were significantly higher than the control group $(p<0.01)$. Levels of ADA and GDA in hepatitis cases were determined as $26.07 \pm 11.98 \mathrm{IU} / \mathrm{l}$ and $2.37 \pm 1.91 \mathrm{IU} / \mathrm{l}$, respectively. When compared their ADA and GDA levels amongst the classified hepatitis groups, there was no difference in ADA levels amongst cases $(p>0.05)$. However, GDA levels in hepatitis A group were closed to the controls. Increase in serum ADA activities in hepatitis forms may be dependent on and reflect the increase in phagocytic activity of macrophages and maturation of T-lymphocytes, and may be valuable in monitoring in viral hepatitis cases.

Key words: adenosine deaminase - guanosine deaminase - viral hepatitis

Adenosine deaminase (ADA, adenosine aminohydrolase, E.C.3.5.4.4.) is an enzyme involved in the catabolism of purine bases, capable of catalysing the deamination of adenosine, forming inosine in the process (Fox \& Kelly 1978). ADA activity is widely distributed in human tissues and is higher in lymphoid tissues, and principal biological activity of ADA is detected in Tymphocytes (Sullivan et al. 1977). Its main physiologic activity is related to lymphocytic proliferation and differentiation. As a marker of cellular immunity, its plasma activity is found to be elevated in diseases in which there is a cell-mediated immune response (Galanti et al. 1981, Piras et al. 1982). It was reported that high serum ADA activities were observed in patients with acute hepatitis, alcoholic hepatic fibrosis, chronic active hepatitis, liver cirrhosis and hepatoma (Kobayashi et al. 1993).

\footnotetext{
$\overline{{ }^{+} \text {Corresponding author. Fax: }}+90-424-237.9138$. E-mail: vbulut@superonline.com.tr Received 16 October 1998 Accepted 12 Februay 1999
}

Guanosine deaminase (GDA, guanosine aminase, E.C. 3.5.4.15) catalyses the formation of xanthosine from guanosine, and is also widely distributed in human tissues (Bairoch 1996).

Hepatitis can be described as an inflammatory process in the liver charactherized by diffuse or patchy hepatocellular necrosis affecting all acini. Hepatitis A virus (HAV) has no known chronic carrier state and plays no role in the production of chronic active hepatitis or cirrhosis. However, prognosis and outcome of acute hepatitis B infection are variable. As a result of subclinical infection, chronic infection occurs frequently in $10 \%$ of infected individuals (Robinson 1995). In general, it is believed that immune system mediated processes play role in the pathogenesis of hepatitis B infection. The mechanisms involved in liver cell injury may be an HLA class I restricted cytotoxic T-cell response directed at $\mathrm{HBcAg} / \mathrm{HBeAg}$ on hepatitis B virus (HBV)-infected hepatocytes, direct cytopathic effect of $\mathrm{HBcAg}$ expression in infected hepatocytes in hepatitis, a direct toxic effect of HBV on liver cells, liver cell injury results from high-level expression and inefficient secretion of HBsAg, and finally co-infection with a second cytopathic virus, the hepatitis delta virus (HDV). During HDV infection, many mechanisms 
may involve in the development of liver lesions as described for HBV.

As to hepatitis $\mathrm{C}$ virus (HCV), the pathogenesis is still to be excluded. Infection with HCV tends to become persistent in most of the infected individuals, apparently reflecting an inability of the immune system to mount an effective antiviral response (Alter et al. 1992).

It is likely that most of hepatitis E virus (HEV) infections are immunopathologic in nature, as with other forms of acute viral hepatitis. Most often, the disease is self-limited. As is the case with hepatitis A, there is no progression to chronic hepatitis, no late hepatic sequel, and no evidence for persistent HEV infection (Brown et al. 1994).

Since relationship exists between ADA activity and the cell mediated immune response, and there is not enough data about ADA and GDA activities in hepatitis due to different viral pathogens, we aimed to determine serum activities of these enzymes in patients with hepatitis and compare with the control group.

\section{MATERIALS AND METHODS}

Subjects - The groups of patients were from Firat Medical Centre in Elazig where hepatitis is endemically present. Subjects were 103 patients divided into four groups with regard to their diagnosis as hepatitis A group ( $\mathrm{n}=13)$, acute cases of hepatitis B $(n=24)$, chronic cases of hepatitis B $(n=49)$ and the group of other hepatitis types-C, $\mathrm{D}, \mathrm{E}(\mathrm{n}=17)$. As a control group, 52 healthy individuals aged 17-47 years from the same area were recruited. Ethical consents were obtained from all participants of this study. Clinical diagnosis of patients was confirmed by serological tests, biopsy specimens and other clinical findings.

Measurement of serum ADA activity - Ten $\mathrm{ml}$ of venous blood were withdrawn and transferred into dry tubes. Having centrifuged at $400 \mathrm{x} g$ for 5 min, serum was separated for serum ADA activity assessment. Serum ADA activity was determined at $37^{\circ} \mathrm{C}$ by a method described by Giusti and Galanti (1984) that was based on the Bertholet reaction. In brief, the formation of colored indophenol complex from ammonia liberated from adenosine and quantified spectrophotometrically. One unit of ADA is defined as the amount of enzyme required to release $1 \mu \mathrm{mol}$ of ammonia/min from adenosine at standard assay conditions. Results were expressed as international unit (IU) of enzyme activity of serum.

Measurement of serum GDA activity - GDA activity was measured as described. Ammonia formed during $30 \mathrm{~min}$ incubation at $37^{\circ} \mathrm{C}$ in the presence of guanine in a phosphate buffer $(\mathrm{pH} 7.4)$ is estimated colorimetrically using a modified phe- nol-alkaline hypochlorite procedure (Caraway 1966).

Measurement of serum aspartate aminotransferase, alanine aminotransferase, and alkaline phosphatase levels - Enzymes required to evaluate the liver function tests were performed by using colorimetric techniques with kit assay systems (Randox, Japan) in Olympus AO 600 autoanalyser system (Olympus, Japan), and performed as described by manufacturers.

Statistical analysis - Student's t test, MannWhitney U and Kruskal-Wallis tests were performed, using a computer program named SPSS for Windows Release 6.0.

\section{RESULTS}

The comparison of enzymatic levels in the sera of viral hepatitis cases with the control group is shown in the Table. All the enzymes, including ADA and GDA enzyme activities, were found to be significantly higher in the cases with hepatitis than the controls $(\mathrm{p}<0.01)$.

For the comparison of enzymatic levels in the sera of hepatitis cases divided into four different groups with regard to their clinical and serological features, such as acute hepatitis A and B, chronic hepatitis B, hepatitis A and other forms of hepatitis. Then, Kruskal-Wallis test was carried out amongst one another. Results are shown in Table. Although ADA activities in all the hepatitis groups are higher than the control group $(\mathrm{p}<0.05)$, no difference in ADA levels was found amongst hepatitis groups ( $p>0.05$ ). However, GDA levels in hepatitis A group was not different from the control group.

\section{DISCUSSION}

Increased serum ADA activities have been observed in many infectious diseases caused by microorganisms infecting mainly the macrophages, in tuberculosis, leprosy, visceral and cutaneous leishmaniasis, brucellosis and, in human deficiency virus (HIV) infection (Gakis et al. 1989, 1991, Valls et al. 1990, Erel et al. 1998). It was reported that 95\% of serologically positive typhoid fever cases found to have increased ADA activity (Ungerer et al. 1996).

Two ADA isozymes are known as ADA1 and ADA2. While human tissue extracts contained ADA1 predominantly, ADA2 was the main component of serum ADA. Therefore, ADA activity measured in serum reflects ADA2 activity. In the report of Kobayashi et al. (1993) it was found that the ADA2:ADA ratio decreased in acute hepatitis, but increased in chronic active hepatitis and liver cirrhosis.

In our opinion, the elevated serum ADA activity in patients with hepatitis may be reflect of ph- 
TABLE

The comparision of enzymatic levels in the sera of hepatitis cases divided into four different groups with regard to their clinical and serological features, such as acute hepatitis A, chronic hepatitis B, hepatitis A and other forms of hepatitis, with the control group is shown. Results were expressed as means \pm SEMs $(p<0.01)$, using Student's t test

\begin{tabular}{lccccc}
\hline & ADA (IU/l) & GDA (IU/l) & AST & ALT & ALP \\
\hline $\begin{array}{l}\text { Acute hepatitis } \\
\text { B cases (n=24) }\end{array}$ & $25.38 \pm 2.48$ & $2.23 \pm 0.24$ & $957.42 \pm 214.56$ & $1352.50 \pm 309.64$ & $377.17 \pm 42.67$ \\
$\begin{array}{l}\text { Chronic hepatitis } \\
\text { B cases (n=49) }\end{array}$ & $27.97 \pm 1.95$ & $2.71 \pm 0.36$ & $98.39 \pm 27.10$ & $137.69 \pm 35.21$ & $169.80 \pm 9.27$ \\
$\begin{array}{l}\text { Hepatitis A } \\
\text { cases (n=13) }\end{array}$ & $24.43 \pm 3.16$ & $1.57 \pm 0.20$ & $1262.54 \pm 394.13$ & $1320.08 \pm 270.59$ & $526.85 \pm 97.16$ \\
$\begin{array}{l}\text { Other hepatitis } \\
\text { cases (n=17) }\end{array}$ & $22.79 \pm 1.06$ & $2.17 \pm 0.12$ & $72.71 \pm 15.78$ & $109.47 \pm 36.82$ & $163.06 \pm 20.45$ \\
$\begin{array}{l}\text { Viral hepatitis } \\
\text { cases (n=103) }\end{array}$ & $26.07 \pm 1.18^{a}$ & $2.37 \pm 0.19^{a}$ & $441.24 \pm 84.01^{a}$ & $565.33 \pm 98.33^{a}$ & $262.07 \pm 20.90^{a}$ \\
$\begin{array}{l}\text { Controls (n=52) } \\
\text { nas }\end{array}$ & $18.62 \pm 0.61$ & $1.76 \pm 0.08$ & $10.42 \pm 0.70$ & $8.23 \pm 0.60$ & $33.73 \pm 1.63$ \\
\hline
\end{tabular}

$a=\mathrm{p}<0.01$; ADA: adenosine deaminase; GDA: guanosine deaminase; AST: aspartate aminotransferase; ALT: alanine aminotransferase; ALP: alkaline phosphatase; IU/l: International Unit/liters.

agocytic activity of macrophages, and may provide useful additional diagnostic information on the pathogenesis of hepatitis. For instance, it is known that editing of antigenomic RNA, generates two distinct forms of delta antigen, is involved in ADA activity (Casey \& Gerin 1995, Monjardino 1996). Since hepatitis delta virus (HDV) is a unique human pathogen associated with hepatitis B infection and molecular pathogenicity of HDV remains to be excluded, the evaluation of ADA activity in sera of patients with hepatitis should be considered as a useful tool to monitorize their clinic. Barnes et al. (1995) reported that adenosine could lessen the potentially damaging activity of neutrophiles at sites of infections. On the other hand, ADA activity counteracts with adenosine by utilizing it. Therefore, development of some ADA inducer drugs or its direct administration may be studied in the future to lessen the risk of chronic liver disease due to hepatitis. In early studies on ADA activity in sera of active and chronic liver diseases, it was suggested that monitorizing of ADA levels in PBMC may show biochemical and/ or histological remission in chronic liver diseases (Nardiello et al. 1983). However, in our study, no difference in ADA levels was found between acute and chronic hepatitis B cases.

Preliminary results of Jones et al. (1983) suggested that GDA increased in hepatitis and in patients with liver metastases, but normalized in all other liver diseases including cirrhosis and obstructive jaundice. However, we could not observe any statistical difference between acute and chronic hepatitis B cases. Then, we would be able to suggest that GDA might be useful as a indicator for liver condition in hepatitis disease. Since its activity in hepatitis A group is as much as in the control group, it may be an explanatory point for the mechanism results in further liver destruction in chronic forms of HBC and HBV hepatitis.

To explain the cause and mechanisms of increased levels of ADA and GDA activities further studies are needed.

\section{REFERENCES}

Alter MJ, Margolis HS, Krawczynski K, Judson FN, Mares A, Alexander WJ, Hu PY, Miller JK, Gerber MA, Sampliner RF 1992. The natural history of community-acquired hepatitis $\mathrm{C}$ in the United States. $N$ Engl J Med 327: 1899-1905.

Bairoch A 1996. The Enzyme data bank in 1995. Nucleic Acids Res 24: 221-222.

Barnes CR, Mandell GL, Carper HT, Luong S, Sullivan GW 1995. Adenosine modulation of tumour necrosis factor-alpha-induced neutrophil activation. Biochem Pharmacol 50: 1851-1857.

Brown EA, Ticehurst J, Lemon SM 1994. Immunopathology of hepatitis A and hepatitis E infection, p.1117. In HC Thomas, J Waters (eds), Immunology of Liver Diseases, Kluwer Academic Publishers, B.V. Dordrecht.

Caraway WT 1966. Colorimetric determination of serum guanase activity. Clin Chem 12:187-193.

Casey JL, Gerin JL 1995. Hepatitis D virus RNA editing: specific modification of adenosine in the antigenomic RNA. J Virol 69: 7593-7600. 
Erel O, Kocyigit A, Gurel MS, Bulut V, Seyrek A, Ozdemir Y 1998. Adenosine deaminase activities in sera, lymphocytes and granulocytes in patients with cutaneous leishmaniasis. Mem Inst Oswaldo Cruz 93: 491-494.

Farci P, Alter HJ, Wong D, Miller RH, Shih JW, Jett B, Purcell RH 1991. A long-term study of hepatitis C virus replication in non-A, non-B hepatitis. $N$ Engl J Med 325: 98-104.

Fox IH, Kelley WN 1978. The role of adenosine deaminase and 2'-deoxyadenosine in mammalian cells. Ann Rev Biochem 47: 655-686.

Gakis G, Calia GM, Natiana AG, Pirino D, Serru G 1989. Serum adenosine deaminase activity in HIV positive subjects. A hypothesis on the significance of ADA-2. Panminerva Med 31: 107-113.

Gakis G, Calia GM, Naitana AG, Ortu AN, Contu A 1991. Serum and pleural adenosine deaminase activity. Chest 99: 1555-1556.

Galanti B, Naddiello S, Russo M, Fiorentino F 1981. Increased lymphocyte adenosine deaminase in typhoid fever. Scand J Infect Dis 13: 47-50.

Giusti G, Galanti B 1984. Adenosine deaminase: colorimetric method, p. 315-323. In HV Bergmeyer, Methods of Enzymatic Analsis, Academic Press, New York.

Jones DD, Roberts EL, Davies AG 1983. The estimation of serum guanosine deaminase activity in liver diseases. J Clin Chem Biochem 21: 835-840.

Kobayashi F, Ikeda T, Marumo F, Sato C 1993. Adenos- ine deaminase isoenzymes in liver disease. Am J Gastroenterol 88: 266-271.

Monjardino J 1996. Replication of hepatitis delta virus. J Viral Hepat 3: 163-166.

Nardiello S, Russo M, Pizzella T, Galanti B 1983. Different levels of lymphocyte adenosine deaminase in active and inactive forms of chronic liver disease. $J$ Clin Lab Immunol 11: 177-180.

Piras MA, Gakis C, Budroni M, Andreoni G 1982. Immunological studies in Mediterrenian spotted fever. Lancet 8283: 1249.

Robinson WS 1995. Hepatitis B virus and Hepatitis D virus, p. 1406-1439. In Mandell GL, Bennet JE, Dolin R (eds), Principles and Practice of Infectious Diseases, Churchill Livingstone Inc., New York.

Sullivan JL, Osborne WR, Wedgwood RJ 1977. Adenosine deaminase activity in lymphocytes. $\mathrm{Br} J$ Haematol 122: 216-220.

Ungerer JP, Burger HM, Bissbort SH, Vermaak WJ 1996. Adenosine deaminase isoenzymes in typhoid fever. Eur J Clin Microbiol Infect Dis 15: 510-512.

Valls V, Ena J, Roca V, Perez-Oteyza C, Angeles Figueredo M, Enriquez-de-Salamanca R 1990. Significance of adenosine deaminase measurement in sera of patients with HIV-1 infection. AIDS 4: 365-366.

Yoakum GH, Korba BE, Lechner JR, Tokiwa T, Gazdar AF, Seeleyt T, Siegel M, Leeman L, Autmp H, Harris CC 1983. High-frequency transfection and cytopathology of hepatitis B virus core antigen gene in human cells. Science 222: 385-389. 